\title{
Permanent education for good practices in the prevention of pressure injury: almost-experiment
}

\author{
Educação permanente para boas práticas na prevenção de lesão por pressão: quase-experimento
}

Educación permanente para buenas prácticas en la prevención de lesión por presión: cuales-experimento

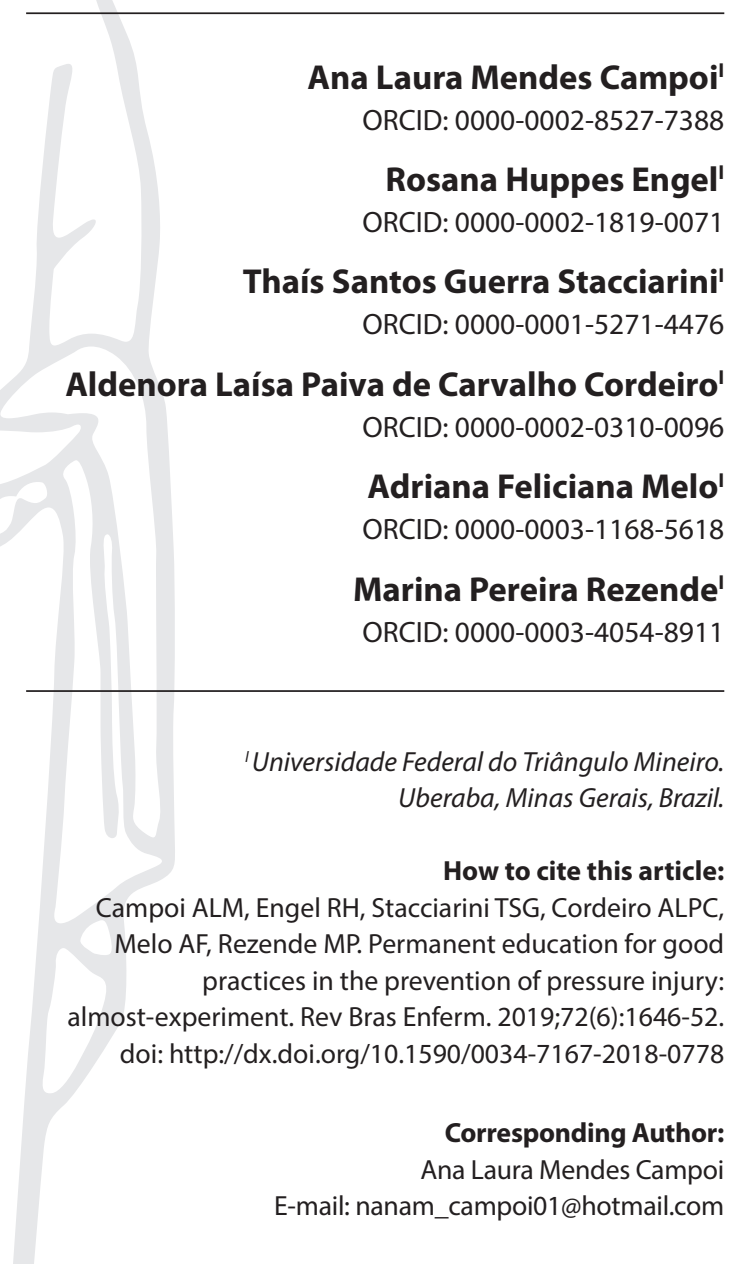

Submission: 10-09-2018 Approval: 03-10-2019

\begin{abstract}
Objective: To verify the effectiveness of the educational intervention through the evaluation of nurses' knowledge about prevention of pressure injury. Method: A quasiexperimental study with a single group, carried out with 95 nurses from a teaching hospital in the interior of Minas Gerais, in August and September 2017. As a teaching strategy, the active methodology and hybrid teaching were used, based on the reference of the Method of the Arch of Charles Maguerez. Data were collected from a validated instrument, called the Pieper Knowledge Test, and analyzed by descriptive statistics and Student's t-test with significance level of $p<0.001$. Results: The mean number of correct answers obtained by the nurses was $78.8 \%$ in the pre-test and $88.8 \%$ in the post-test, and the difference was statistically significant $(p<0.001)$. Conclusion: The educational intervention developed was effective, since it contributed to the improvement of nurses' knowledge.

Descriptors: Pressure Ulcer; Nursing; Patient Safety; Continuing Education; Secondary Prevention.
\end{abstract}

\section{RESUMO}

Objetivo: Verificar a efetividade da intervenção educativa por meio da avaliação do conhecimento dos enfermeiros sobre prevenção de lesão por pressão. Método: Estudo quase-experimental com um único grupo, realizado com 95 enfermeiros de um hospital de ensino do interior de Minas Gerais, nos meses de agosto e setembro de 2017. Como estratégia de ensino, utilizou-se a metodologia ativa e o ensino híbrido, baseado no referencial do Método do Arco de Charles Maguerez. Os dados foram coletados a partir de um instrumento validado, denominado Teste de Conhecimento de Pieper, e analisados por estatística descritiva e teste $t$ de Student com nível de significância de $p<0,001$. Resultados: A média de acertos obtida pelos enfermeiros foi de $78,8 \%$ no pré-teste e $88,8 \%$ no pósteste, sendo a diferença estatisticamente significativa $(p<0,001)$. Conclusão: A intervenção educativa desenvolvida foi efetiva, uma vez que contribuiu para o aprimoramento do conhecimento dos enfermeiros.

Descritores: Lesão por Pressão; Enfermagem; Segurança do Paciente; Educação Continuada; Prevenção de Doenças.

\section{RESUMEN}

Objetivo: Verificar la efectividad de la intervención educativa por medio de la evaluación del conocimiento de los enfermeros sobre prevención de lesión por presión. Método: Estudio cuasi-experimental con un solo grupo, realizado con 95 enfermeros de un hospital de enseñanza del interior de Minas Gerais, en los meses de agosto y septiembre de 2017. Como estrategia de enseñanza, se utilizó la metodología activa y la enseñanza híbrida , basado en el referencial del Método del Arco de Charles Maguerez. Los datos fueron recolectados a partir de un instrumento validado, denominado Test de Conocimiento de Pieper, y analizados por estadística descriptiva y test t de Student con nivel de significancia de $p<0,001$. Resultados: La media de aciertos obtenidos por los enfermeros fue de $78,8 \%$ en el pre-test y $88,8 \%$ en el post-test, siendo la diferencia estadísticamente significativa ( $p$ $<0,001)$. Conclusión: La intervención educativa desarrollada fue efectiva, ya que contribuyó para el perfeccionamiento del conocimiento de los enfermeros.

Descriptores: Úlcera por Presión; Enfermería; Seguridad del Paciente; Educación Continua; Prevención de Enfermedades. 


\section{INTRODUCTION}

Pressure ulcers (PU) are one of the main adverse events found in health services, being one of the most common consequences of long stay in hospitals ${ }^{(1)}$. According to the American National Pressure Ulcer Advisory Panel (NPUAP) (2), the PU is a damage in the skin and/or underlying tissues, usually over a bony prominence, resulting from isolated or combined pressure with shear forces and/or friction, as well as from microclimate, nutrition, perfusion and tissue conditions. Its occurrence is associated not only with care failures, but also with the factors inherent in the individual cared for, which increases the risks of developing the injury ${ }^{(3)}$.

A study ${ }^{(4)}$ carried out in a university hospital with 77 patients admitted to the intensive care unit (ICU) pointed that the incidence of PU was $22 \%$. Other studies ${ }^{(5-6)}$ showed incidence of PU ranging from $25.8 \%$ to $50 \%$. The high incidence is directly related to the patients' high risk of developing the PU, according to the Braden scale ${ }^{(7)}$, and the first week of hospitalization is the period in which most of the injuries arise ${ }^{(8)}$.

Considered a persistent health problem, the PU causes patients and their families to suffer, generates cost and increases the workload of the nursing teams that play a central role in care $^{(3)}$. In this regard, adopting preventive measures to reduce its occurrence is important, since it is considered a key indicator of care quality ${ }^{(9)}$. Among the nursing care actions for prevention of $\mathrm{PU}$, one highlights the importance of decubitus change, whose benefit is to decompress areas over bony prominences ${ }^{(1)}$.

It is essential that nurses seek constant improvement in its practices to implement measures aimed at identifying risk factors of $\mathrm{PU}$, so that the integrity of the patient's skin during the period of hospitalization can be maintained and thus a good quality care can be provided ${ }^{(10)}$.

In this context, the continuing education aimed at the nursing staff is an important action in health services, because it allows updating the professionals' knowledge and improving care. Still, it assists in the transformation of reality through the articulation between the theory and practice appplied by workers, mediated by institutional policies that support these actions ${ }^{(11)}$.

Regarding the new pedagogical tendencies, active methodology is one of the possible strategies for training critical-reflective professionals, that is, co-responsible for the production of their own learning process, from the observation of social reality, understanding of the problem through scientific-theoretical basis and raising off hypothesis to solve the problems identified ${ }^{(12)}$.

In addition, digital technologies have provided changes in education, which can be observed with the creation of several modalities of distance learning, including hybrid teaching, combining classroom activities and distance educational activities, focused on values, skills and knowledge construction ${ }^{(13)}$.

Therefore, hybrid education is defined as the union of two models of learning: the classroom model, in which the process occurs in the classroom; and the online model, which uses digital technologies to promote education. One can consider that both of these learning environments become complementary, because the subject interacts with the group, intensifying the exchange of experiences that occurs in the classroom ${ }^{(13)}$.
Considering that, the question that guided this study was: How effective is the educational intervention on nurses' knowledge regarding the prevention of PU?

\section{OBJETIVE}

To verify the effectiveness of educational intervention by assessing nurses' knowledge on pressure ulcer preventive measures.

\section{METHOD}

\section{Ethical aspects}

This study is part of the project entitled "Continuing education as a strategy of training and management for quality and safety in nursing care", approved by the Research Ethics Committee (REC) of a university. The data collection tools were applied after signing of the informed consent form (ICF). Anonymity was guaranteed, since the participants were identified by a number.

\section{Study design}

It is a quasi-experimental study with a single group, conducted in a large teaching hospital, which offers high-complexity care, located in Minas Gerais.

\section{Inclusion criteria}

The population of this study consisted of nurses of the aforementioned institution, totaling 178 professionals. The inclusion criteria were: to work as an outreach nurse at a hospital and to be enrolled in the educational intervention. Nurses who were on leave or medical license/maternity leave were excluded from this study. The non-probabilistic sample was composed of 95 nurses, after losses: professionals who were enrolled but did not attend the educational intervention; and professionals who did not attend all stages of the educational intervention. Figure 1 shows the sample loss.

These professionals were recruited from the inscription for participation in the course on prevention of $\mathrm{PU}$, offered by the service of education in nursing (SEE) of the institution, according to goal of the Strategic Director Plan (PDE) for the biennium 2017-2018.

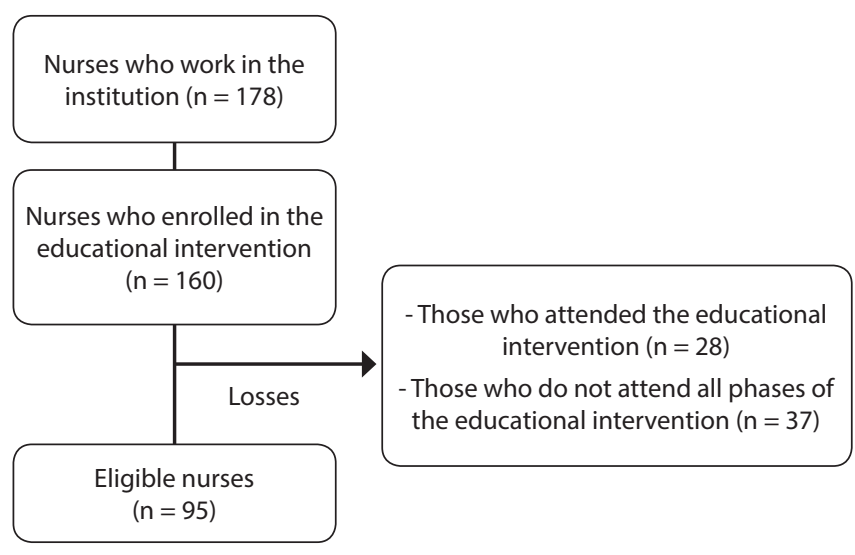

Figure 1 - Nurses eligible for participation in the educational intervention, according to the inclusion and exclusion criteria, Minas Gerais, Brazil, 2018 


\section{Study protocol}

The educational intervention, performed in August and September 2017, was guided by the problematization method, based on the Method of the Arch by Charles Maguerez, consisting of five steps: observation of reality, key points, theorizing, hypotheses of solution and application to reality ${ }^{(12)}$. Figure 2 shows the steps of the educational intervention adopted, based on the Arch of Maguerez:
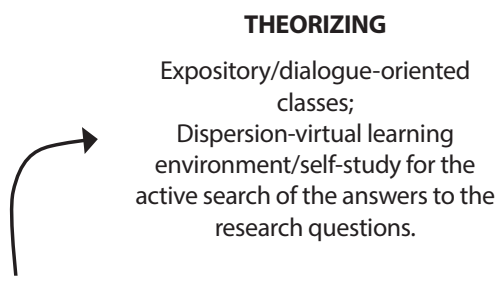

\section{KEY POINTS}

Formulation of hypotheses (cause - consequence proposals for solutions) in group;

Framing of research questions

to support the discussion in activity of the forum

"Situation-Problem" in the virtual environment.

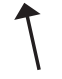

Identification of challenges to the reduction in the occurrence of $\mathrm{PU}$ through nurses.

\section{OBSERVATION OF REALITY}

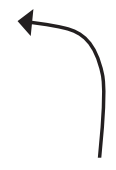

\section{HYPOTHESIS OF SOLUTION}

Presentation of the chances of a solution to the problem, based on the experience of nurses and on evidences; Time-based learning Workshop - prescription of nursing from the cases presented by the facilitators.

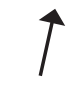

\section{APPLICATION TO REALITY}

Midterm evaluation - routinely after the educational intervention.

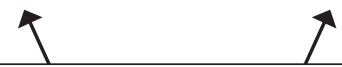

Reality: Incidence of pressure ulcer (PU) in the hospital of this study

Figure 2 - Stages of educational intervention based on the Method of the Arch by Maguerez, Minas Gerais, Brazil, 2018

Paulo Freire advocates the problematizing education ${ }^{(14)}$, based on the inseparability of the contexts and the life stories in the training of subjects, arguing that the learner's previous knowledge must be respected and exploited. In addition, the author reveals that teaching is not the transference of knowledge, but the creation of possibilities for its own production or development; for this purpose, the stimulus to curiosity and active stance are the tools used, encouraging the critical analysis of reality.

Hybrid education was a teaching strategy used in the course, in which the nurses had three face-to-face moments (one meeting per week) combined with interactivity in the Virtual Learning Environment (VLE) of the university: Moodle. Being a VLE, Moodle is an online education administration system of educational activities aimed at promoting interactivity and learning ${ }^{(15)}$.

The VLE was used throughout the course based on the theme discussed in person, containing classes, videos, materials of the Ministry of Health and scientific articles, forum for group discussion and activities, such as a basis of photos of PU for identification of stages according to the characteristics of the injuries ${ }^{(2)}$. All of this sought to involve the participants in active participation, interactivity and solving of daily life problems.

The face-to-face moments included dialogue expository classes and teaching-learning tools based on active methodology. In the first face-to-face meeting, the contents addressed in class included the theme "Pathophysiology and classification of the PU". The tool used by the facilitators was the "situation-problem", which aimed to identify the problems that contribute to a higher incidence of PU in the institution. Then, the participants had seven days for virtual interactivity in the Moodle before the second face-to-face meeting.

In the second face-to-face meeting, the theme was "Welfare quality indicator: monitoring of PU". The tool used was"team-based learning", which assisted in understanding multidimensional problems related to the incidence of PU and the importance of monitoring them. At the end of the meeting, the nurses were encouraged to carry on the activities, by accessing the VLE, for more seven days. The theme of the third and last face-to-face meeting was "Nursing process in the prevention of PU". A "workshop" that considered the structure of the nursing process was done for development of skills to identify the risk of PU and to prescribe precautions. Finally, one more virtual meeting completed the educational intervention. The total workload was 30 hours, being 12 hours in the classroom and 18 hours of distance teaching.

For data collection, two instruments were used: one consisting of sociodemographic data, elaborated by the authors (gender, age, job sector, higher degree of training in the field) and the Pieper Knowledge Test, to assess the participants' level of knowledge of the prevention of $\mathrm{PU}$, composed of 41 questions in form of statements to indicate true $(T)$, false $(F)$ or uncertain $(\mathrm{U})$, validated and adapted to Brazil ${ }^{(16)}$. The right answers are real statements answered as "V" or false ones answered as " $\mathrm{F}$ ". Each right answer received one point, and no points were assigned to the wrong answers and to questions whose answers were $U$. The Pieper Knowledge Test, to which nurses answered individually, was administered before and after the educational intervention.

\section{Analysis of results and statistics}

The data collected were tabulated in a Excel spreadsheet and analyzed using the statistical software of the program Statistical Package for Social Sciences (SPSS), version 21.0. Descriptive statistics was used to design measures of central tendency, frequencies and dispersion for demographic variables. The Student's t-test was used to compare the averages of right answers before and after the educational intervention. The significance level set was $p<0.001$.

\section{RESULTS}

Ninety-five nurses of the hospital participated in the study, with an average age of 33.47 years, ranging from 23 to 70 years old. Regarding higher degree of training in the field, $12.6 \%$ of nurses have only undergraduate course, $73.7 \%$ of them have a specialization course; $12.6 \%$, master's degree; and $1.1 \%$, doctorate degree. When considering the average of right answers before the intervention and the professional's training, those having only graduation reached an 
average of $76.6 \%$ right answers; those with specialization, and average of $79.7 \%$ right answers; masters, an average of $76.1 \%$; and doctors, an average of $73.2 \%$. Regarding the average of right answers after the intervention, in the above order, $91.9 \%$ were graduated; $88.5 \%$ were specialists; $87.3 \%$, masters; and $82.9 \%$, doctors.

With regard to another job, only $11.6 \%$ of the nurses have more than one job. In relation to the average of right answers, the nurses who have another job reached a score of $81 \%$ in the pre-intervention test and, after the training, it increased to $89.7 \%$. The average of right answers of those who have only one job was $78.5 \%$ before the intervention, increasing to $88.8 \%$ in the final phase of the intervention.

When assessing the nurses' score in the pretest, a variation from $60.9 \%$ to $90.2 \%$ of right answers (average of $78.8 \%$ ) was observed, and, in the posttest, the score ranged from $68.3 \%$ to $100 \%$ (average of $88.8 \%)$, with a statistically significant difference $(p<0.001)$. Table 1 shows the results obtained by the nurses by doing the knowledge test before and after the educational intervention.

Table 1 - Percentage of right answers of the nurses, according to the items of the Pieper Knowledge Test, before and after the educational intervention, Minas Gerais, Brazil, 2018

\begin{tabular}{ccc}
\hline & \multicolumn{2}{c}{ Nurses (N = 95) } \\
Questions - Pieper Knowledge Test & Right & Right \\
answers & answers \\
& Pretest & Posttest \\
& $n \%$ & n $\%$ \\
\hline
\end{tabular}

1 The stage 1 of the pressure ulcer is characterized $\begin{array}{llll}72 & 75.8 & 92 & 96.8\end{array}$ by intact skin, with hyperemia in a localized area, which shows no visible blanching or whose color differs from the surrounding area. (T)

2 The risk factors for the development of pressure $\quad 90 \quad 94.7 \quad 92 \quad 96.8$ ulcer are: impaired mobility, incontinence, inadequate nutrition and change in the level of consciousness. ( $\mathrm{T}$ )

3 All patients at risk for pressure ulcer should have a systematic skin inspection at least once a week. (F)

4 The use of hot water and soap may dry the skin and increase the risk for pressure ulcers. (T)

5 Massage of bony prominences is important in case of hyperemia in such areas. $(F)$

6 A Stage 3 pressure ulcer is a partial thickness skin loss, involving the epidermis. (F)

7 All individuals should be assessed on admission to a hospital for risk of pressure ulcer development. (T)

8 The creams, transparent dressings and extra fine hydrocolloid dressings help in protecting the skin against the effects of friction. (T)

9 Stage 4 pressure ulcers show a full thickness skin loss with extensive destruction and

tissue necrosis, or damage to muscle, bone, or supporting structure. ( $\mathrm{T}$ )

10 An adequate dietary intake of proteins and calories should be maintained during illness/ hospitalization. ( $\mathrm{T}$ )

11 Patients confined to bed should be repositioned every 3 hours. (F)

121 A turning schedule should be used for each patient at risk for or with pressure ulcer. (T)

$\begin{array}{llll}92 & 96.8 & 93 & 97.9\end{array}$

$9195.8 \quad 95 \quad 100$

\begin{tabular}{ccc}
\hline & Nurses ( $=95)$ \\
Questions - Pieper Knowledge Test & Right & Right \\
answers & answers \\
Pretest & Posttest \\
& n $\%$ & n $\%$ \\
\hline
\end{tabular}

$\begin{array}{llllll}13 & \text { Water-filled/air-filled gloves relieve pressure on } \quad 22 & 23.1 & 85 & 89.5\end{array}$ calcanei. (F)

14 Air or water donut cushions help to prevent $\quad \begin{array}{llll}10 & 10.5 & 71 & 74.7\end{array}$ pressure ulcers. (F)

15 In a side lying position, a patient with or at risk $\quad 3941.1 \quad 69 \quad 72.6$ for pressure ulcer should be at a 30 degree angle with the bed. (T)

16 In a patient with or at risk for pressure ulcer, the head of the bed should be maintained at an angle no higher than 30 degrees, if there is no medical contraindication. ( $T$ )

17 A patient who cannot move him or herself should be repositioned every 2 hours while sitting in a chair. (F)

$18 \mathrm{~A}$ patient with impaired mobility who can move him/herself without aid should be taught to shift his/her weight every 15 minutes for relief of pressure, while sitting in a chair. $(\mathrm{T})$

19The patient with impaired mobility who can remain in the chair should be fitted for a cushion for protection of the areas of bony prominences. $(T)$

20 Stage 2 pressure ulcers present full thickness skin loss. (F)

21 The skin of a patient at risk for pressure ulcer should remain clean and dry. ( $T$ )

22 Preventive measures against new injuries do not need to be adopted continuously when the patient already has pressure ulcer. $(F)$

23 Sliding sheets or underpads should be used to transfer or move patients who cannot move themselves without aid. ( $T$ )

24 Mobilization and transfer of patients who do not move themselves without aid should always be performed by two or more people. (T)

25 For the patient with chronic condition who does not move himself/herself without aid, rehabilitation must be initiated and include orientations on the prevention and treatment of pressure ulcer. ( $\mathrm{T}$ )

26 Every patient who does not walk must be submitted to risk assessment concerning the development of pressure ulcer. ( $\mathrm{T}$ )

$\begin{array}{llll}30 & 31.6 & 67 & 70.5\end{array}$

$\begin{array}{llll}32 & 33.7 & 47 & 49.5\end{array}$

$\begin{array}{llll}52 & 54.7 \quad 82 & 86.3\end{array}$

$\begin{array}{llll}79 & 83.2 \quad 80 & 84.2\end{array}$

$\begin{array}{llll}61 & 64.2 & 64 & 67.4\end{array}$

$\begin{array}{llll}91 & 95.8 \quad 95 & 100\end{array}$

$\begin{array}{lll}89 & 93.7 \quad 92 & 96.8\end{array}$

$\begin{array}{llll}83 & 87.4 \quad 87 & 91.6\end{array}$

$94 \quad 98.9 \quad 94 \quad 98.9$

$95 \quad 100 \quad 95 \quad 100$

27 Patients and family members should be oriented regarding the causes and risk factors for the development of pressure ulcer. $(T)$

28 Bony prominences should not have direct contact with one another. (F)

29 Every person assessed to be at risk for

developing pressure ulcers should be placed on a pressure-redistribution bed surface. $(T)$

30 Skin macerated from moisture tears more easily. (T)

31 Pressure ulcers are sterile wounds. (F)

$32 \mathrm{~A}$ pressure ulcer scar will break down faster than unwounded skin. (T)

$92 \quad 96.8 \quad 9498.9$

$95 \quad 100 \quad 95 \quad 100$

$92 \quad 96.8 \quad 95 \quad 100$

$\begin{array}{llll}81 & 85.3 & 64 & 67.4\end{array}$

$95 \quad 100 \quad 94 \quad 98.9$

$\begin{array}{llll}75 & 78.9 & 71 & 74.7\end{array}$

$\begin{array}{llll}71 & 74.7 \quad 83 & 87.4\end{array}$

33 A blister on the heel is nothing to worry about. (F) $92 \quad 96.8 \quad 95 \quad 100$ 34 A good way to decrease pressure on the heels is to $7174.7 \quad 8690.5$ elevate them off the bed. (T) 


\begin{tabular}{|c|c|c|c|c|}
\hline \multirow{3}{*}{ Questions - Pieper Knowledge Test } & \multicolumn{4}{|c|}{ Nurses $(\mathbf{N}=95)$} \\
\hline & \multicolumn{2}{|c|}{$\begin{array}{l}\text { Right } \\
\text { answers } \\
\text { Pretest }\end{array}$} & \multicolumn{2}{|c|}{$\begin{array}{l}\text { Right } \\
\text { answers } \\
\text { Posttest }\end{array}$} \\
\hline & $\mathbf{n}$ & $\%$ & $\mathbf{n}$ & $\%$ \\
\hline $\begin{array}{l}35 \text { All care given to prevent or treat pressure } \\
\text { ulcers do not need to be documented. (F) }\end{array}$ & 94 & 98.9 & 95 & 100 \\
\hline $\begin{array}{l}36 \text { Shear is the force that occurs when the skin } \\
\text { sticks to a surface and the body slides. (T) }\end{array}$ & 81 & 85.3 & 85 & 89.5 \\
\hline $\begin{array}{l}37 \text { Friction may occur when moving a person up } \\
\text { in bed. }(T)\end{array}$ & 91 & 95.8 & 90 & 94.7 \\
\hline $\begin{array}{l}38 \text { Stage } 2 \text { pressure ulcers may be extremely } \\
\text { painful due to exposure of nerve endings. (T) }\end{array}$ & 45 & 47.4 & 50 & 52.6 \\
\hline $\begin{array}{l}39 \text { For persons who have incontinence, skin } \\
\text { cleaning should occur at the time of soiling and at } \\
\text { routine intervals. (T) }\end{array}$ & 92 & 96.8 & 93 & 97.9 \\
\hline $\begin{array}{l}40 \text { Developing educational programs in the } \\
\text { institution may reduce the incidence of pressure } \\
\text { ulcers. }(T)\end{array}$ & 95 & 100 & 95 & 100 \\
\hline $\begin{array}{l}41 \text { Hospitalized patients need to be evaluated as } \\
\text { to the risk for pressure ulcer at least once during } \\
\text { their hospitalization. (F) }\end{array}$ & 95 & 100 & 94 & 98.9 \\
\hline
\end{tabular}

Note: True (T); False (F); Number of nurses: $n$.

The nurses answered $100 \%$ of questions correctly in the preintervention questionnaire in items $25,27,30,40$ and 41 , which, in general, address the need for orienting patients and their families about the prevention, causes and risk factors of PU, as well as the reduction in the incidence of PU through educational programs in the institution.

Items 5, 13 and 14 of the pre-intervention test had the lowest percentage of right answers (49.5\%, $23.1 \%$ and $10.5 \%$, respectively), related to massage of areas with hyperemia, use of water-filled or air-filled gloves and of donut cushions to prevent PU. After the training, improvement in those items was observed, since they show a percentage of right answers of $95.8 \% 89.5 \%$, and $74.7 \%$, respectively.

\section{DISCUSSION}

Since the incidence of PU in hospitalized patients impacts the quality of the care provided, the adoption of good practices through the improvement in the prevention of PU is necessary. Knowledge is essential to behavior change.

The results of this study indicate that the nurses had previous knowledge of the prevention of PU, considering the average of right answers they scored in the pretest (78.8\%), despite some weaknesses found.

A similar ${ }^{(17)}$ study with 40 nursing professionals of an ICU at a university hospital in Manaus identified an average of $51.4 \%$ of right answers for nurses in the categories of the Pieper Knowledge Test; thus, verifying knowledge deficit about prevention of $\mathrm{Pu}$, which makes the training of these professionals fundamental.

A study ${ }^{(18)}$ conducted in Sweden with 415 participants, among which were nurses and nursing students, suggests the need for an educational program focused on the nursing staff due to the deficiency of knowledge of these professionals about the prevention of PU.
Such weaknesses in the nurses' knowledge impact directly the patient's safety, since it favors the occurrence of undesirable effects of health care, affecting the service quality. Given the scale of the problem, aimed at reducing adverse events and achieving a safe care, the World Health Organization (WHO) launched the World Alliance for Patient Safety, encouraging the adoption of the International Patient Safety Goals, among them the prevention of PUs ${ }^{(3)}$.

The nurses answered correctly $100 \%$ of the questions of the items describing the importance of orientation about PU and reduction in its incidence through educational programs, namely, the professionals perceive the need for prevention. However, the occurrence of this adverse event is still considered a problem in hospitals, which suggests the prevention methods are not as effective as thought or are not being used properly ${ }^{(19)}$.

The data presented showed the questions the nurses failed to answer more frequently were related to the nursing care that are currently contraindicated in the prevention of PU, such as: massage of areas with hyperemia, use of water-filled or air-filled gloves and of donut cushions to prevent PU. This datum corroborates studies that, when assessing the nurses' knowledge, identified lower percentage of right answers to the same items, demonstrating the importance of updating and in-service training ${ }^{(20-21)}$.

The use of hybrid teaching and active methodology as a focus of educational intervention for improvement in nurses regarding the prevention of PU showed satisfactory results, since there was no statistically significant difference $(p<0.001)$ when considering the average of right answers before and after the intervention (from $78.8 \%$ to $88.8 \%$ ).

Problem-based learning contributes to the applicability of the concepts learned, since it begins with the presentation of a problem and involves discussion and research in group ${ }^{(22)}$. Active methodologies with digital technologies enable better learning through practices, activities, games, problems when compared with the conventional method ${ }^{(13)}$, in addition to allowing flexibility for the conduction of the activities, once they help in overcoming the barrier of time and space ${ }^{(23)}$.

Still, they provide quick access to a large piece of information by modifying the ways of thinking and developing knowledge; therefore, their role should be considered concerning modifications they cause in the ways of thinking and in behavioral changes of those who use them or are surrounded by them ${ }^{(13)}$.

In Brazil, one believes that hybrid teaching is the modality capable of introducing changes in classroom teaching and in distance courses, considering that they favor the students'learning in all aspects ${ }^{(24)}$.

The use of outdated techniques for prevention unveils the need for update and affects the nurse's competence profile, since the lack of knowledge reflects in the skills and attitudes of professionals when caring for patients at risk of PU.

In relation to the prevention of $\mathrm{PU}$, knowledge is not enough, we need to improve skills and attitudes, which comprises the three main matrices of competence - knowing, knowing how to do, and wanting to do ${ }^{(25)}$. The knowledge of the prevention of PU is considered a basic content in the nurses' training, and the everyday practice of the competence is the tool for a safe and good quality care ${ }^{(26)}$. 
The Pieper Knowledge Test, used in this study, allowed assessing the nurses' cognitive skills regarding the prevention of $\mathrm{PU}$, whereas the attitudinal competencies were addressed in the educational intervention adopted in the course, through the active methodology and hybrid education.

\section{Study limitations walk}

This study showed limitations related to the quasi-experimental design with a single group, since it had neither control group nor randomization.

\section{Contributions to the fields of nursing, health or public policy}

In regard to the contributions, it enabled the identification of the main knowledge deficits of the nurses on the prevention of $\mathrm{PU}$, besides verifying the effectiveness of the active methodology and hybrid education as tools for continuing education.

In addition, an institutional protocol for the prevention of PU was designed and a report of the study on the main problems contributing to the incidence of PU identified by the nurses who participated in the course was sent to the management of the hospital, as well as the hypotheses of solutions proposed by these professionals to standardize actions and improve the quality of the nursing care provided in the institution. The results found in this study point to the need for investment in the training of professionals through the education services of hospitals.

\section{CONCLUSION}

One highlights that the nurses had knowledge on the prevention of PU before the intervention, considering the average of right answers in the pretest (78.8\%). However, this study pointed some weaknesses in the knowledge, considering that these professionals still use old-fashioned prevention techniques, which points the need for updating and in-service training.

The educational intervention adopted showed satisfactory results, since no statistically significant difference was found $(p<0.001)$ when considering the average of right answers before and after the intervention (from $78.8 \%$ to $88.8 \%$ ), which shows the action is effective, once it contributed to improving the nurses' knowledge.

One suggests that new studies adopt the educational strategy presented here and evaluate knowledge acquisition for educational planning. In addition, encouraging the nurses' attitudinal and psychomotor skills in relation to the prevention of PU is necessary, on behalf of patient safety.

\section{REFERENCES}

1. Pereira MO, Ludvich SC, Omizzolo JAE. Segurança do paciente: Prevenção de úlcera por pressão em unidade de terapia intensiva. Rev Inova Saúde. 2016;5(2):29-44. doi: 10.18616/is.v5i2.3009

2. National Pressure Ulcer Advisory Panel (NPUAP). National Pressure Ulcer Advisory Panel (NPUAP) announces a change in terminology from pressure ulcer to pressure injury and updates the stages of pressure injury [Internet]. 2016 [cited 2017 May 26]. Available from: http://www. npuap.org/national-pressure-ulcer-advisory-panel-npuap-announces-a-change-in-terminology-from-pressure-ulcer-to-pressure-injuryand-updates-the-stages-of-pressure-injury/

3. Agência Nacional de Vigilância Sanitária (ANVISA). Assistência Segura: Uma Reflexão Teórica Aplicada à Prática [Internet]. Brasília; 2013 [cited 2017 Dec 18]. Available from: http://www.saude.pr.gov.br/arquivos/File/OSEGURANCA_DO_PACIENTE/Modulo_1AssistenciaSegura.pdf.

4. Borghardt AT, Prado TN, Bicudo SDS, Castro DS, Bringuente MEO. Pressure ulcers in critically ill patients: incidence and associated factors. Rev Bras Enferm. 2016;69(3):431-8. doi: 10.1590/0034-7167.2016690307i

5. Louro M, Ferreira M, Póvoa P. Avaliação de protocolo de prevenção e tratamento de úlceras de pressão. Rev Bras Ter Intensiva. 2007;19(3):337-41. doi: 10.1590/S0103-507X2007000300012

6. Fernandes NCS, Torres GV. Incidência e fatores de risco de úlceras de pressão em pacientes de unidade de terapia intensiva. Ciênc Cuid Saúde. 2008;7(3):304-10. doi: 10.4025/cienccuidsaude.v7i3.6484

7. Paranhos WY, Santos VLCG. Avaliação de risco para úlceras por pressão por meio da Escala de Braden, na língua portuguesa. Rev Esc Enferm USP [Internet]. 1999 [cited 2018 Jul 09];33(n.esp.):191-206. Available from: http://www.ee.usp.br/reeusp/upload/pdf/799.pdf

8. Matos LS, Duarte NLV, Minetto RC. Incidência e prevalência de úlcera por pressão no CTI de um Hospital Público do DF. Rev Eletr Enf. 2010;12(4):719-26. doi: 10.5216/ree.v12i4.8481

9. Santos CT, Oliveira MC, Pereira AGS, Suzuki LM, Lucena AF. Pressure ulcer care quality indicator: analysis of medical records and incident report. Rev Gaúcha Enferm. 2013;34(1):111-8. doi: 10.1590/S1983-14472013000100014

10. Lima PR, Damacena DEL, Neves VLS, Campos RBN, Silva FAA, Bezerra SMG. Ocorrência de lesão por pressão em pacientes hospitalizados: uma revisão integrativa. Rev Uningá Review [Internet]. 2017 [cited 2018 Mar 8];32(1):53-67. Available from: http://revista.uninga.br/index. php/uningareviews/article/view/39/446

11. Cavalcante EFO, Macêdo MLAF, Oliveira JSA, Martini JG, Backes VMS. Practice of continuous educations for nursing in health services. Rev Enferm UFPE. 2013;7(2):598-607. doi: 10.5205/reuol.3073-24791-1-LE.0702201335

12. Prado ML, Velho MB, Espíndola DS, Sobrinho SH, Backes VMS. Arco de Charles Maguerez: refletindo estratégias de metodologia ativa na formação de profissionais de saúde. Esc Anna Nery. 2012;16(1):172-7. doi: 10.1590/S1414-81452012000100023

13. Bacich L, Tanzi Neto A, Trevisani FM. Ensino híbrido: personalização e tecnologia na educação. Porto Alegre: Penso; 2015. 
14. Freire P. Pedagogia da Autonomia: saberes necessários à prática educativa. 25a ed. São Paulo: Paz e Terra; 1996.

15. Rostas MHSG, Rostas GR. O Ambiente Virtual de Aprendizagem (MOODLE) como ferramenta auxiliar no processo de ensino aprendizagem: uma questão de comunicação. In: Soto U, Mayrink MF, Gregolin IV, organizadoras. Linguagem, Educação e Virtualidade: experiências e reflexões. São Paulo: Cultura Acadêmica; 2009. p. 135-151.

16. Fernandes LM, Caliri MHL, Haas VJ. Efeito de intervenções educativas no conhecimento dos profissionais de enfermagem sobre prevenção de úlceras pressão. Acta Paul Enferm. 2008;21(2):305-11. doi: 10.1590/S0103-21002008000200012

17. Galvão NS, Serique MAB, Santos VLCG, Nogueira PC. Knowledge of the nursing team on pressure ulcer prevention. Rev Bras Enferm [Internet]. 2017;70(2):294-300. doi: 10.1590/0034-7167-2016-0063

18. Gunningberg L, Mårtensson G, Mamhidir AG, Florin J, Athlin ÅM, Bååth C. Pressure ulcer knowledge of registered nurses, assistant nurses and student nurses: a descriptive, comparative multicentre study in Sweden. Int Wound J. 2013;12(4):462-8. doi: 10.1111/iwj.12138

19. Wong AL, Walia GS, Bello R, Aquino CS, Sacks JM. Pressure ulcer prevalence and perceptions on prevention: a hospital-wide survey of health professionals. J Wound Care. 2018;27(Supl 4):S29-S35. doi: 10.12968/jowc.2018.27.Sup4.S29

20. Miyazaki MY, Caliri MHL, Santos CB. Conhecimento dos profissionais de enfermagem sobre prevenção da úlcera por pressão. Rev Latino-Am Enfermagem. 2010;18(6):1203-11. doi: 10.1590/S0104-11692010000600022

21. Mauricio AB, Lemos DS, Crosewski NI, Roehrs H. Conhecimentos dos profissionais de enfermagem relacionados às úlceras por pressão. Rev Enferm UFSM. 2014;4(4):751-760. doi: 10.5902/2179769211707

22. Souza SC, Dourado L. Aprendizagem baseada em problemas (ABP): um método de aprendizagem inovador para o ensino educativo. Holos. 2015;31(5):182-200. doi: 10.15628/holos.2015.2880

23. Sousa RP, Moita FMCSC, Carvalho ABG. Tecnologias digitais na educação [Internet]. Campina Grande: EDUEPB;2011 [cited 2018 Jul 09]. Available from: http://www.clam.org.br/bibliotecadigital/uploads/publicacoes/1484_991_sousa-9788578791247.pdf

24. Valente JA. Blended learning e as mudanças no ensino superior: a proposta da sala de aula invertida. Educ Rev. 2014;4(n.esp):79-97. doi: $10.1590 / 0104-4060.38645$

25. Furukawa PO, Cunha ICKO. Da gestão por competências às competências gerenciais do enfermeiro. Rev Bras Enferm. 2010;63(6):1061-6. doi: 10.1590/S0034-71672010000600030

26. Moura ECC, Caliri MHL. Simulation for the development of clinical competence in risk assessment for pressure ulcer. Acta Paul Enferm. 2013;26(4):369-75. doi: 10.1590/S0103-21002013000400011 